\title{
Program Pemberdayaan Masyarakat Kampung Asuh di Kelurahan Pakal Kecamatan Pakal Kota Surabaya
}

\author{
Erwan Aristyanto ${ }^{1}$, Allen Pranata Putra ${ }^{2}$, Riduwan ${ }^{3}$, Nanang Qosim ${ }^{4}$ \\ Universitas Wijaya Putra ${ }^{1,2}$, STAI YPBWI ${ }^{3,4}$ \\ erwanaristyanto@uwp.ac.id, allenpranata@uwp.ac.id, ridwan.zainal05@gmail.com, \\ m.nanang.qosim.mjk@gmail.com
}

\begin{abstract}
Abstrak
Kondisi Pandemi Covid 19 ini mempengaruhi sektor pendidikan baik di tingkat dasar hingga perguruan tinggi. Kebijakan dari Pemerintah melalui aturan Menteri Pendidikan dan Kebudayaan Republik Indonesia terkait Surat Edaran Nomor 4 Tahun 2020 tentang Kebijakan Pelaksanaan Pendidikan Dalam Masa Darurat Penyebaran Virus Covid 19 di Indonesia. Berbagai media pembelajaran jarak jauh di gunakan dalam mendukung pembelajaran melalui internet agar proses belajar mengajar dapat di laksanakan dalam waktu yang bersamaan meskipun di tempat berbeda. Dalam pelaksanaan pembelajaran secara daring menimbulkan dampak yang dirasakan baik dari pendidik, siswa maupun orang tua siswa terutama pada tingkat pendidikan dasar. Tujuan dari pengabdian masyarakat ini adalah memberikan solusi terhadap permasalahan mitra antara lain, kurangnya kegiatan positif pada anak yang sangat rawan terpapar dampak negatif penggunaan internet seperti kecanduan game online, pornografi dan permasalahan dalam bersosialisasi serta keterbatasan pengetahuan orang tua dalam mendampingi siswa dalam belajar online, banyak orang tua yang tidak siap karena sudah di sibukkan dengan pekerjaan di luar rumah maupun di dalam rumah serta tertinggal secara teknologi. Metode yang digunakan adalah pendampingan personal terhadap mitra, tim pengabdian akan melakukan pendampingan dalam membangun komunitas Al Qur'a. Hasil dari pengabdian masyarakat ini bahwa prosentase kehadiran mampu meningkatkan efektifitas komunitas Qur'an bagi penguatan belajar anak - anak.
\end{abstract}

Keywords : Dampak Pandemi, Kegiatan Positif, Komunitas Al Qur’an, Kampung Asuh 


\section{PENDAHULUAN}

\section{a. Analisis Situasi}

Program Kegiatan Masyarakat sebagai bentuk kontribusi yang diwujudkan oleh para akademisi demi mendukung program pemerintah berdasarkan perundang-undangan. Kelurahan Pakal merupakan bagian dari Kecamatan Pakal Kota Surabaya, terdiri dari 4 Kelurahan yaitu Kelurahan Babat Jerawat, Kelurahan Benowo, Kelurahan Pakal dan Kelurahan Sumberejo. Hampir 200 KK yang berada di RT 03 RW 02 Kelurahan Pakal, terdapat daerah kaplingan yang mayoritas penduduknya adalah warga pendatang. Di daerah kaplingan sendiri terdapat hampir $50 \mathrm{KK}$. Dampak pandemi covid 19 ini mempengaruhi kegiatan di RT ini, banyak kegiatan yang tidak bisa di lakukan secara normal terutama anak - anak. Anak merupakan amanah dari Allah SWT yang di percayakan kepada kedua orang tua untuk di besarkan, dididik dan di biasakan dalam kebaikan. Namun dalam kenyataannya, tidak semua anak dapat melewati proses perkembangannya dengan baik, sejumlah faktor yang berasal dari keluarga dan lingkungan dapat mempengaruhi perkembangan dan perilakunya dalam kehidupan. Pola asuh orang tua adalah suatu keseluruhan interaksi antara orang tua dengan anak, dimana orang tua bermaksud menstimulasi anaknya dengan mengubah tingkah laku, pengetahuan serta nilai-nilai yang dianggap paling tepat oleh orang tua agar anak dapat tumbuh dan berkembang secara optimal.

Kondisi Pandemi Covid 19 ini banyak mempengaruhi dan mengancam berbagai sektor, salah satunya adalah sektor pendidikan. Memasuki era adaptasi kebiasaan baru atau new normal beberapa sektor sudah beraktifitas kembali dengan memperhatikan protokol kesehatan, namun dalam bidang pendidikan masih belum melakukan aktifitas seperti biasa dan masih menggunakan pembelajaran melalui daring. Semua jenjang pendidikan baik di tingkat dasar hingga perguruan tinggi harus terpaksa melakukan pembelajaran dari rumah melalui jaringan internet. Hal tersebut merupakan kebijakan dari Pemerintah melalui aturan Menteri Pendidikan dan Kebudayaan Republik Indonesia terkait Surat Edaran Nomor 4 Tahun 2020 tentang Kebijakan Pelaksanaan Pendidikan Dalam Masa Darurat
Penyebaran Virus Covid 19 di Indonesia. Berbagai media pembelajaran jarak jauh di gunakan dalam mendukung pembelajaran melalui internet agar proses belajar mengajar dapat di laksanakan dalam waktu yang bersamaan meskipun di tempat berbeda. Dalam pelaksanaan pembelajaran secara daring menimbulkan dampak yang dirasakan baik dari pendidik, siswa maupun orang tua siswa terutama pada tingkat pendidikan dasar. Berdasarkan observasi yang di lakukan tim pengabdian masyarakat terdapat beberapa permasalahan yang di hadapi misalnya keterbatasan pada kepemilikan handphone yang dapat digunakan untuk pembelajaran daring, keterbatasan paket data internet yang kuotanya membutuhkan biaya tinggi, keterbatasan pengetahuan orang tua dalam mendampingi siswa dalam belajar online, banyak orang tua yang tidak siap karena sudah di sibukkan dengan pekerjaan di luar rumah maupun di dalam rumah serta tertinggal secara teknologi. Permasalahan siswa yang sangat rawan terpapar dampak negatif penggunaan internet seperti kecanduan game online, pornografi, kurangnya minat baca serta permasalahan dalam bersosialisasi ( Arifah Prima Satrianingrum, Lis Prasetyo, 2021 ).
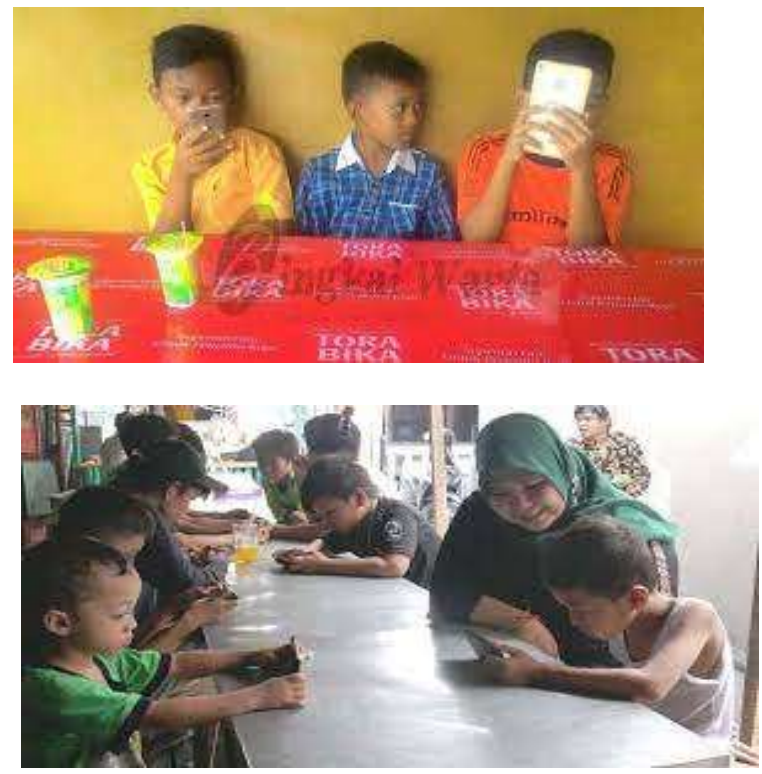

Gambar 1. Penggunaan gadget pada anak 


\section{b. Identifikasi Permasalahan Spesifik Mitra}

Berdasarkan latarbelakang tersebut, maka tim mengidentifikasi spesifik aspek - aspek permasalahan mitra sebagai berikut :

Tabel 1. Perruasalahan dan Solusis untak MIitra

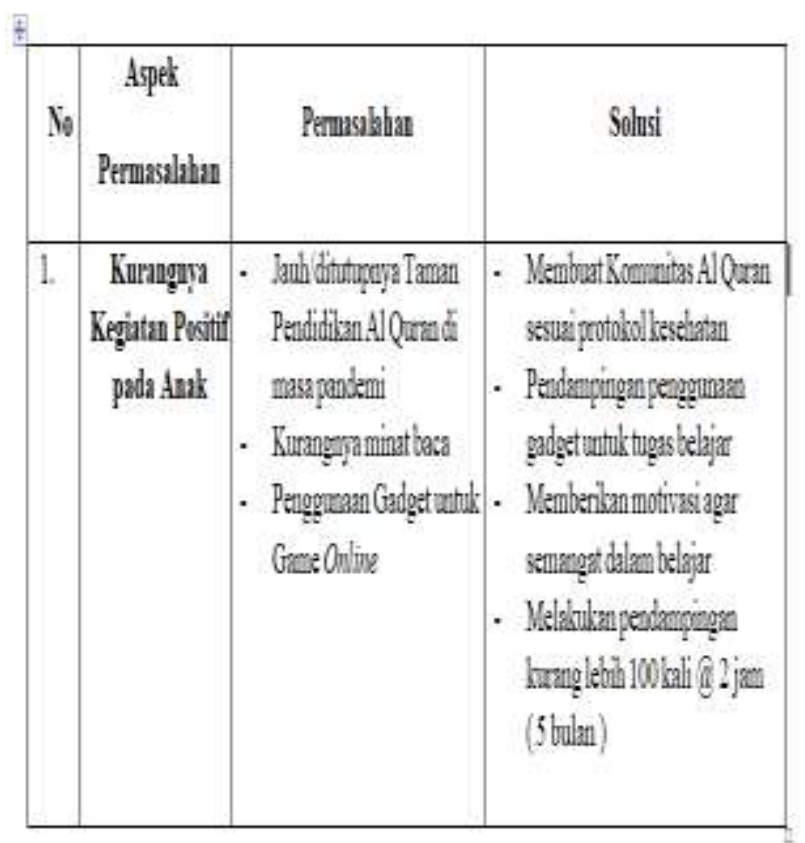

\section{c. Tujuan Kegiatan}

1. Membantu mitra dalam memberikan kegiatan positif pada anak sehingga di harapkan mitra tetap bisa beraktifitas seperti sebelum ada pandemi, tentunya dengan mengikuti arahan program kesehatan dari pemerintah.

2. Membantu mitra dalam pembinaan pola asuh yang disesuaikan dengan kondisi psikologis masing - masing orang tua.

\section{d. Metode Kegiatan}

1. Melakukan negosiasi dengan tokoh masyarakat dan sesepuh untuk menyampaikan tujuan program sekaligus menyusun teknis pelaksanaan kegiatan.

2. Planning yaitu merencanakan tahapan kegiatan melalui joint kampung asuh community

3. Collecting the Data menggunakan FGD

4. Actuating and Monitoring ( Pelaksanaan dan Pengawasan )

5. Evaluation and Result Report ( Mengevaluasi dan pelaporan hasil dengan menggunakan observasi, wawancara, dokumentasi dan catatan di lapangan )

\section{METODE}

Metode menggunakan Community Based Research yaitu pengabdian masyarakat berbasis riset ( Karen Hacker, Comunity Based Participatory Research, 2013 ). Pendekatan dalam pengabdian masyarakat ini untuk mengkaji dan memperoleh makna yang lebih mendalam dari kegiatan yang di laksanakan yaitu mengukur efektifitas komunitas Qur'an bagi penguatan belajar anak - anak pada Program Pemberdayaan Masyarakat di Kelurahan Pakal Kecamatan Pakal Kota Surabaya. Kelompok sasaran kegiatan adalah anak - anak pra sekolah dasar hingga menengah pertama di Kelurahan Pakal Kecamatan Pakal Kota Surabaya. Kegiatan di laksanakan pada bulan April hingga Agustus 2021. Tahapan dalam Kegiatan Program Pemberdayaan Masyarakat di Kelurahan Pakal Kecamatan Pakal Kota Surabaya adalah sebagai berikut:

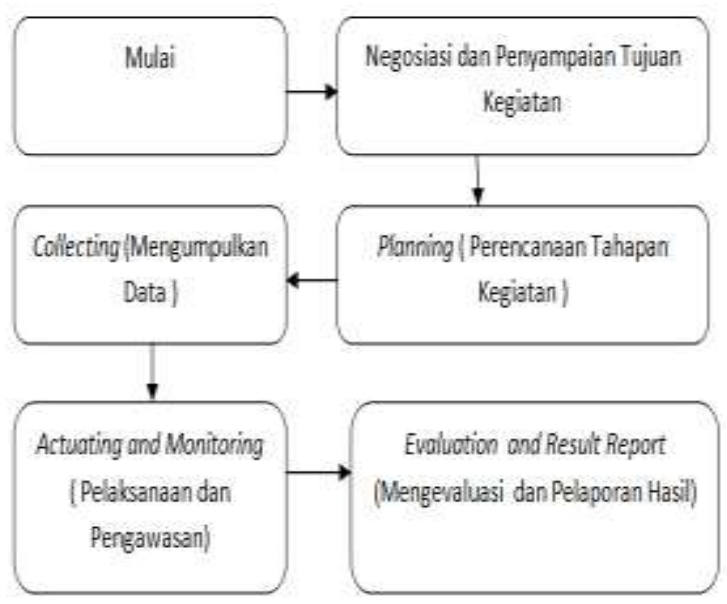

Gambar 2. Tahapan dalam Kegiatan Program Pemberdayaan Masyarakat di Kelurahan Pakal Kecamatan Pakal Kota Surabaya

\section{HASIL DAN PEMBAHASAN a. Gambaran Umum}

Berdasarkan metode pelaksanaan kegiatan yang di tawarkan tim pengabdian masyarakat mitra dari Program Pemberdayaan Masyarakat Kampung Asuh di Kelurahan Pakal Kecamatan Pakal Kota Surabaya. Peserta melakukan tes kemampuan baca Al Qur'an anak meliputi tajwid, tahsin dan makhorijul huruf bacaan. 
Tabel 2. Kemampuan Awal Baca Al Qur'an Mitra

\begin{tabular}{|c|c|c|c|c|c|}
\hline $\mathrm{N}_{0}$ & NamaAnak & Jetis Kelamin & Usia & Kitab & Keterangan \\
\hline 1 & Noral & L & 13 & AlQur'a & Juz 30 \\
\hline 2 & Iham & $\mathrm{L}$ & 13 & AlQur'in & Jaz? \\
\hline 3 & Rafid & $\mathrm{L}$ & 13 & AlQui'a & Juz 1 \\
\hline 4 & Azyo & P & 12 & AlQur'an & $\mathrm{Juz} 30$ \\
\hline 5 & Asjyah & $P$ & 12 & AlQur'm & Juz 1 \\
\hline 6 & Salina & $P$ & 11 & AlQur'in & $\mathrm{Juz} 1$ \\
\hline 7 & Fendi & $\mathrm{L}$ & 10 & AlQur'm & Juz 1 \\
\hline 8 & Rafi & $\mathrm{L}$ & 10 & Inga & Jilid? \\
\hline 9 & Wildan & $\mathrm{L}$ & 10 & Inpa & Jilid 3 \\
\hline 10 & $\mathrm{Ngila}$ & $P$ & 10 & Inga & Iilid 4 \\
\hline 11 & Yoxil & $\mathrm{L}$ & 9 & Inga & Jilid? \\
\hline 12 & Riso & $\mathrm{L}$ & 8 & Belum biss & Belum bisa \\
\hline 13 & Atiga & $P$ & 6 & Belum bisa & Belum bisa \\
\hline 14 & Syita & $P$ & 6 & Belum biss & Belum bisa \\
\hline 15 & Sultion & $\mathrm{L}$ & 6 & Belimm bisa & Belum bisa \\
\hline 16 & Nagla & $P$ & 6 & Bellum biss & Belum bisa \\
\hline 17 & Jalu & $\mathrm{L}$ & 6 & Befum bisa & Belum bisa \\
\hline 18 & Zalki & $\mathrm{L}$ & 5 & Befum bisa & Belum bisa \\
\hline
\end{tabular}

Dari hasil kemampuan awal di ketahui bahwa kemampuan baca mitra, 7 anak sudah bisa baca Al Qur'an, namun secara tajwid ( tahsin bacaan ) perlu di tingkatkan kemampuannya. 11 anak masih belum bisa membaca Iqra dan hampir semuanya dalam tahapan jilid 1 .

Pendampingan dalam Program Pemberdayaan Masyarakat Kampung Asuh di Kelurahan Pakal Kecamatan Pakal Kota Surabaya berlangsung sesuai dengan rencana yang di susun sebelumnya. Kegiatan dilakukan secara tatap muka dari hari Senin hingga Jum'at dimulai dari jam 15:30 WIB sampai menjelang Magrib,dibagi menjadi dua kelompok dan wajib menggunakan masker, jaga jarak serta berwudhu terlebih dahulu. Kegiatan di lakukan antara bulan April hingga Agustus 2021.
Model pelatihan komunitas Al Qur'an yang di terapkan adalah dengan menulis, membaca, mendengar dan menyimak bacaan serta dengan melihat video teladan tokoh - tokoh islam. Pada setiap kehadiran setiap peserta memperoleh hadiah agar tetap semangat dalam mengikuti kegiatan Program Pemberdayaan Masyarakat Kampung Asuh di Kelurahan Pakal Kecamatan Pakal Kota Surabaya (Eriandika Dewanto dkk, 2020).

\section{b. Hasil Kemampuan Anak}

Hasil kemampuan anak - anak tingkat sekolah dasar hingga sekolah menengah pertama setelah mengikuti pelatihan komunitas baca $\mathrm{Al}$ Quran Program Pemberdayaan Masyarakat Kampung Asuh di Kelurahan Pakal Kecamatan Pakal Kota Surabaya adalah sebagai berikut :

Tabel 3. Hasil Kemampuan Baca Al Qur'an

Mitra Setelah Mengikuti Program

Pemberdayaan Masyarakat Kampung Asuh di

Kelurahan Pakal Kecamatan Pakal Kota Surabaya

\begin{tabular}{|c|c|c|c|c|c|}
\hline Bo & Trass hask & Shetron & Sexdah & Rekation (X) & Retrangar \\
\hline 1 & Boral & 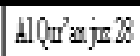 & 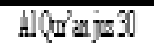 & 90 & Noinhbul je \\
\hline 2 & Tham & AlQt'a $j=2$ & HlQp'anjut & 8 & Bafil tekexpa suet \\
\hline 3 & Pifid & AlQt'orys! & AlQtr'ajus? & 80 & Bxfalbeteryis and. \\
\hline 4 & 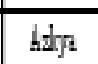 & 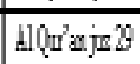 & 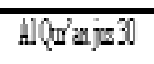 & 90 & Bxfalbekespa and. \\
\hline 5 & higrth & HQtu' & AlQu'dajus & 8 & Bxfal beteraph and \\
\hline 6 & Sabre & AlQt'ajz! & 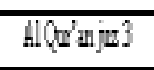 & 8 & Bdal bekerpa sat. \\
\hline 1 & Perti & HQt'ajul & 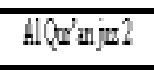 & 8 & Bxal bekexpasad. \\
\hline 8 & $8: G$ & 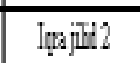 & Irpjill & 80 & 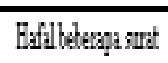 \\
\hline 9 & Tilan & Impajint3 & lypalits & 8 & 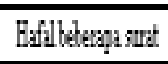 \\
\hline 10 & Mij] & Impaid & 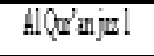 & 8 & Bufil bekerna ard. \\
\hline II & ?"wil & Irojajith & lepill3 & 80 & 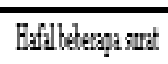 \\
\hline 12 & Pion & Betantisa & $\operatorname{lng} 2012$ & 80 & 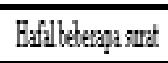 \\
\hline 13 & thige & Betuntisa & lypjill & 90 & Bxfal beteraph and \\
\hline 14 & Syh & Betuntisa & 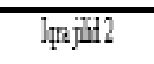 & 8 & Bxfal beterạn sut. \\
\hline 15 & Suthon & Betuntisa & Jypint2 & 8 & Bafilbeterpinased. \\
\hline 16 & Wyjla & Betuntisa & Jprijlit2 & 80 & \\
\hline 17 & Jeln & Belunicise & Iqrowis' & 80 & \\
\hline 18 & Zasli & Bermbitis & Tequetis & 80 & \\
\hline
\end{tabular}

Pendidikan 686 
Berdasarkan tabel Hasil kemampuan anak - anak tingkat sekolah dasar hingga sekolah menengah pertama setelah mengikuti pelatihan dan pendampingan komunitas baca Al Quran Program Pemberdayaan Masyarakat Kampung Asuh di Kelurahan Pakal Kecamatan Pakal Kota Surabaya. Ananda Noval sebelum mengikuti kegiatan sudah bisa membaca Al Qur'an pada juz 28 dan setelah mengikuti kegiatan dengan prosentase kehadiran $90 \%$, bacaannya sudah pada juz 30 serta sudah mulai menghafal 1 juz. Ananda Ilham sebelum mengikuti kegiatan sudah bisa membaca Al Qur'an pada juz 2 dan setelah mengikuti kegiatan dengan prosentase kehadiran $85 \%$, bacaannya sudah pada juz 4 serta sudah mulai menghafal beberapa surat surat pendek. Ananda Rafid sebelum mengikuti kegiatan sudah bisa membaca Al Qur'an pada juz 1 dan setelah mengikuti kegiatan dengan prosentase kehadiran $80 \%$, bacaannya sudah pada juz 2 serta sudah mulai menghafal beberapa surat - surat pendek. Ananda Azkya sebelum mengikuti kegiatan sudah bisa membaca Al Qur'an pada juz 29 dan setelah mengikuti kegiatan dengan prosentase kehadiran $90 \%$, bacaannya sudah pada juz 30 serta sudah mulai menghafal beberapa surat - surat pendek. Ananda Aisyah sebelum mengikuti kegiatan sudah bisa membaca Al Qur'an pada juz 1 dan setelah mengikuti kegiatan dengan prosentase kehadiran $85 \%$, bacaannya sudah pada juz 3 serta sudah mulai menghafal beberapa surat - surat pendek. Ananda Salwa sebelum mengikuti kegiatan sudah bisa membaca Al Qur'an pada juz 1 dan setelah mengikuti kegiatan dengan prosentase kehadiran $85 \%$, bacaannya sudah pada juz 3 serta sudah mulai menghafal beberapa surat - surat pendek. Ananda Ferdi sebelum mengikuti kegiatan sudah bisa membaca Al Qur'an pada juz 1 dan setelah mengikuti kegiatan dengan prosentase kehadiran $85 \%$, bacaannya sudah pada juz 3 serta sudah mulai menghafal beberapa surat - surat pendek. Ananda Rafi sebelum mengikuti kegiatan sudah bisa membaca Iqra Jilid 2 dan setelah mengikuti kegiatan dengan prosentase kehadiran $80 \%$, bacaannya sudah Iqra Jilid 3 serta sudah mulai menghafal beberapa surat - surat pendek. Ananda Wildan sebelum mengikuti kegiatan sudah bisa membaca Iqra Jilid 3 dan setelah mengikuti kegiatan dengan prosentase kehadiran $85 \%$, bacaannya sudah Iqra Jilid 5 serta sudah mulai menghafal beberapa surat - surat pendek. Ananda
Najla sebelum mengikuti kegiatan sudah bisa membaca Iqra Jilid 4 dan setelah mengikuti kegiatan dengan prosentase kehadiran 85\%, bacaannya sudah tahap Al Qur'an pada juz 1 serta sudah mulai menghafal beberapa surat - surat pendek. sudah bisa membaca Al Qur'an pada juz 1. Ananda Yusril sebelum mengikuti kegiatan sudah bisa membaca Iqra Jilid 2 dan setelah mengikuti kegiatan dengan prosentase kehadiran $80 \%$, bacaannya sudah Iqra Jilid 3 serta sudah mulai menghafal beberapa surat - surat pendek. Ananda Rico sebelum mengikuti kegiatan belum bisa membaca Al Qur'an dan setelah mengikuti kegiatan dengan prosentase kehadiran $80 \%$, bacaannya sudah Iqra Jilid 2 serta sudah mulai menghafal beberapa surat - surat pendek. Ananda Atiqa sebelum mengikuti kegiatan belum bisa membaca Al Qur'an dan setelah mengikuti kegiatan dengan prosentase kehadiran 90\%, bacaannya sudah Iqra Jilid 3 serta sudah mulai menghafal beberapa surat - surat pendek. Ananda Syifa sebelum mengikuti kegiatan belum bisa membaca Al Qur'an dan setelah mengikuti kegiatan dengan prosentase kehadiran $85 \%$, bacaannya sudah Iqra Jilid 2 serta sudah mulai menghafal beberapa surat - surat pendek. Ananda Shulthon sebelum mengikuti kegiatan belum bisa membaca Al Qur'an dan setelah mengikuti kegiatan dengan prosentase kehadiran $85 \%$, bacaannya sudah Iqra Jilid 2 serta sudah mulai menghafal beberapa surat - surat pendek. Ananda Nayla sebelum mengikuti kegiatan belum bisa membaca Al Qur'an dan setelah mengikuti kegiatan dengan prosentase kehadiran 80\%, bacaannya sudah Iqra Jilid 2. Ananda Jalu sebelum mengikuti kegiatan belum bisa membaca Al Qur'an dan setelah mengikuti kegiatan dengan prosentase kehadiran $80 \%$, bacaannya sudah Iqra Jilid 2. Ananda Zakki sebelum mengikuti kegiatan belum bisa membaca Al Qur'an dan setelah mengikuti kegiatan dengan prosentase kehadiran $80 \%$, bacaannya sudah Iqra Jilid 1( Ivka Zuhrotun Najiha, 2015). Berdasarkan data - data tersebut dapat di simpulkan bahwa seluruh proses kegiatan berjalan dengan baik dan telah memperoleh capaian target yang di harapkan di mana hampir semua peserta mengalami peningkatan kemampuan walaupun ada beberapa yang peserta yang masih belum optimal. Rujukan terhadap taraf kehadiran dan keberhasilan pada Program Pemberdayaan Masyarakat Kampung Asuh di Kelurahan Pakal Kecamatan Pakal Kota Pendidikan 687 
Surabaya berpatokan kepada standart capaian kehadiran minimal. Tabel rujukan standar capaian kehadiran minimal adalah sebagai berikut :

Tabel 4. Taraf Kehadiran dan Keberhasilan

\begin{tabular}{|c|c|c|}
\hline $\begin{array}{c}\text { Prosentase Kehadiran } \\
(\%)\end{array}$ & Sebutan & Bemasil/ Tidak \\
\hline $80-100$ & Baik Sekali & Bembasil \\
\hline $70-79$ & Baik & Bembsil \\
\hline $60-69$ & Cukup & Tidak \\
\hline$<60$ & Kurang & Tidak \\
\hline
\end{tabular}

Dari pemaparan tabel taraf kehadiran dan keberhasilan terlihat bahwa dengan semakin tinggi kehadiran peserta dalam kegiatan komunitas Al Qur'an telah mempercepat tercapainya target Program Pemberdayaan Masyarakat Kampung Asuh di Kelurahan Pakal Kecamatan Pakal Kota Surabaya (Nora Afnita, Ismail Makki 2018).

\section{KESIMPULAN}

Berdasarkan penjelasan hasil kegiatan Program Pemberdayaan Masyarakat Kampung Asuh di Kelurahan Pakal Kecamatan Pakal Kota Surabaya dapat di simpulkan bahwa Komunitas Al Quran sangat berperan penting dalam beberapa capaian antara lain :

1. Anak - anak tetap bisa belajar Al Qur'an walaupun dengan memakai masker, jaga jarak dan bersuci terlebih dahulu dari sebelumnya Taman Pendidikan Al Quran di masa pandemi di masa pandemi Covid 19.

2. Anak - anak dapat melihat video tokoh tokoh islam kemudian merangkum dan menjelaskan pesan dari cerita tersebut sehingga meningkatkan minat menulis dan membaca.

3. Anak - anak tetap bisa menggunakan gadget namun penggunaan gadget untuk Game Online menjadi lebih sedikit daripada sebelumnya.

4. Orang tua peserta merasa sangat terbantu dan berterima kasih dengan kegiatan ini, sehingga mengurangi tingkat stres dan emosinya.

\section{SARAN}

Program Pemberdayaan Masyarakat Kampung Asuh di Kelurahan Pakal Kecamatan Pakal Kota Surabaya bisa dilanjutkan untuk pembuatan TPQ di Mushola di daerah sekitar agar memperoleh hasil yang lebih optimal ( Nuraini, 2018).

\section{UCAPAN TERIMAKASIH}

Dengan selesainya kegiatan pengabdian ini, maka kami sampaikan trerimakasih yang sebesar - besarnya kepada Rektor Universitas Wijaya Putra, Dekan Fakultas Ekonomi dan Bisnis, LPPM beserta jajarannya yang telah memberikan dukungan penuh terhadap dana kegiatan ini sehingga dapat berjalan lancar. Terimaksih juga untuk seluruh keluarga di Kelurahan Pakal Kecamatan Pakal Kota Surabaya sebagai mitra yang telah memberikan kesempatam tim dalam melakukan pengabdian ini.

\section{REFERENSI}

Arifah Prima Satrianingrum, Lis Prasetyo, 2021.

Persepsi Guru Dampak Pandemi Covid 19 terhadap Pelaksanaan Pembelajaran Daring di PAUD. Jurnal Obsesi; Jurnal Pendidikan Anak Usia Dini. Vol 05 N0 01 Hal 633640. Universitas Negeri Yogyakarta.

Eriandika Dewanto dkk, 2020. Pendampingan

Belajar Bagi Anak Sekolah di masa

Pandemi Covid .19 di Kecamatan

Sukorame. Lapkknunnes . Universitas

Negeri Semarang

Ivka Zuhrotun Najiha, 2015. Pembinaan Akhlakul Karimah Bagi Anak di TPQ Al Falah Desa Bakal Kecamatan Batur Kabupaten Banjarnegara. Skripsi. Fakultas Tarbiyah dan Ilmu Keguruan IAIN Purwokerto

Karen Hacker, 2013. Community Based Participatory Research. Institute for Community Health. Cambridge Health Allience. Harvard Medical School. USA SAGE Publication Inc. 
Prosiding PKM-CSR, Vol.43 (2021)

e-ISSN:2655-3570

Nora Afnita, Ismail Makki 2018. Membangun Komunitas Rumah Tahfidz Anak Untk Percepatan Program Magrib Mengaji. Annual Conference on Comunity Engagement.

Nuraini, 2018. Strategi Mengelola Rumah Tahfiz Aisyah Binjai Sumatera Utara

DalamMenghafal Al Quran Bagi Para Santri. Skripsi. Fakultas Dakwah dan Komunikasi Universitas Islam Negeri Sumatera. 